\title{
Does the Governed Corporation Perform Better? \\ Governance Structures and Corporate Performance in Germany
}

\author{
Erik Lehmann ${ }^{*}$ and Jürgen Weigand ${ }^{* *}$
}

February 2000

\footnotetext{
* Department of Economics, University of Konstanz, P.O. box D-144, D-78457 Konstanz, Germany email: erik.lehmann@uni-konstanz.de
}

** CPB The Netherlands Institute of Economic Policy Analysis, 2508 GM Den Haag, Postbus 80510, The Netherlands, and Ameritech research scholar, Institute for Development Strategies, Indiana University, USA, Institute for Development Strategies, SPEA 201, Bloomington, Indiana 47405-2100, USA emails: jcw@cpb.nl, jweigand@indiana.edu

\section{Acknowledgments}

The authors are indebted to Bob Chirinko for his insightful comments and suggestions as well as to an anonymous referee for a detailed report and substantial advice. Helpful comments were also received from David Audretsch, Hans Degryse, Paul De Grauwe, Julie Ann Elston, Oliver Fabel, Rainer Feuerstack, Günther Franke, Carolin Frohlin, Sabine Langner, Manfred Neumann, Marco Pagano, Hans-Jürgen Ramser, and participants in conference sessions at the 1999 Meetings of the Western Economic Association (San Diego), European Finance Association (Helsinki), European Economic Association (Santiago de Compostela), the European Association for Research in Industrial Economics (Torino) and workshops or seminars at the University of Central Florida, Humboldt University Berlin, University of Konstanz, and Katholieke Universiteit Leuven. The second author would also like to thank Ulrich Hege, Piet Moerland, and Luc Renneboog for stimulating background discussions. The authors gratefully acknowledge financial support from the German Research Council (Deutsche Forschungsgemeinschaft) and the Bundesland Mecklenburg-Vorpommern. 


\begin{abstract}
The paper investigates the impact of corporate governance on the performance of 361 German corporations over the time period 1991 to 1996. We find ownership concentration to affect profitability significantly negatively. Representation of owners on the board of executive directors does not make a difference. The profitability-ownership concentration relation depends on both stock market exposure and the location of control rights. The negative effect of ownership concentration can be traced back to family- or foreign-owned non-quoted firms as well as quoted firms with different large shareholders. A positive impact of ownership concentration on profitability, supportive of managerial discretion and agency theories, shows up for quoted firms which have financial institutions as large shareholders. Our results imply that (1) the presence of large shareholders does not necessarily enhance profitability, and (2) the high degree of ownership concentration seems to be a sub-optimal choice for many of the tightly held German corporations.
\end{abstract}

\title{
JEL classification: G3, L1
}

Key words: firm performance, ownership concentration, governance structures, managerial discretion 
Shareholders are stupid and impertinent - stupid, because they give their funds to somebody else without adequate control, and impertinent, because they clamor for a dividend as a reward for their stupidity.

Carl Fürstenberg (1850-1933), German financier

\section{Introduction}

Ever since Berle and Means (1932) stated that in the modern corporation hired managers have enough discretion for corporate plundering, the issue of separating ownership from control and its resulting impact on firm performance has been placed high on the agenda of economists. Globalizing product and financial markets have recently triggered renewed interest in the link between corporate governance and performance among academics and business press. As firms face new challenges from increased cross-border competition, pressures to adapt to a new internationally integrated environment mount. Thus, the question currently being debated in Europe and in the USA is whether established systems of corporate finance and corporate control are still appropriate to cope with the challenges ahead. ${ }^{1}$

A prime element of corporate governance is the alignment of shareholders' interests with the interests of managers hired to run the firm. In this respect the Anglo-American system relies heavily on the market mechanism to channel the flow of capital, to control its efficient use, and to assure investors of maximizing the return on their investments. Active markets for corporate control function as a disciplinary mechanism to sanction badly performing firms. The threat of corporate takeovers is supposed to reign in free-wheeling managers. ${ }^{2}$ As markets for equity capital are highly liquid, dissatisfied shareholders can easily sell off their holdings. The benefits typically attributed to this so-called market-based system are seen in a better provision of finance to innovative start-up firms and higher returns to investors. The 
system, however, has been criticized for short-termism, neglect of interests other than shareholders', and inefficiency in delivering effective corporate governance. ${ }^{3}$

In the literature on managerial discretion and agency costs it has been argued that the presence of a large shareholder reduces agency costs because a high stake in the firm makes it the shareholder's very interest to control the executive managers hired to run the firm. ${ }^{4}$ Ownership concentration thus may be the key to effective corporate governance and shareholder value maximization.

Concentrated ownership is a salient feature of the German system of corporate governance. ${ }^{5}$ German corporations tend to have only one large blockholder who often commands a super-majority interest. Small and medium-sized firms, preferably organized as private partnerships or limited liability corporations, are typically majority-owned by individuals (families) or are subsidiaries of large firms. Joint stock corporations with widely dispersed outside shareholdings, as is common in the USA or the UK, are very rare. ${ }^{6}$ The German stock market is still of relatively small size regarding listings and market capitalization. ${ }^{7}$ Ownership structures are observed to be unchanged over decades, since large shareholders tend to stick to their blockholdings even in times of very bad corporate performance. Further, close ties between industrial firms and financial institutions (banks) (e.g. via cross-shareholdings, long-term lenderborrower relations) seem to foster access to debt capital, thus reducing the need to attract equity capital via the stock market. The network-like structure of the German system has effectively thwarted any serious attempts of (un)friendly take-overs. An active market for corporate control rights does not exist despite the recent take-over battle between Mannesmann and Vodafone. However, in view of high unemployment and sluggish growth critics see the network-orientation as a root cause for entrepreneurial inertia, risk aversion, and low investment in emerging new technologies or infant industries. It has been recommended to dispose of the German system of corporate governance or, at least, modify it by incorporating elements of the market-based Anglo-American system. ${ }^{8}$ 
As noted by Mayer (1996), "Despite the intense debate, evidence on the effects of different governance systems is still sparse." Most of the available empirical evidence on the governance-performance link is based on Anglo-Saxon data. Therefore, the present paper aims to contribute to the on-going corporate governance debate by providing empirical evidence on German corporations. We investigate the impact of corporate governance indicators such as ownership concentration, stock market exposure, board representation of owners, and the location of control rights on profitability. In Section 2, the link between corporate governance and firm performance as well as previous empirical evidence on Germany are discussed in more detail. Section 3 presents the empirical analysis for a panel data set of 361 German corporations over the time period 1991 to 1996. In Section 4, we summarize and conclude. In particular, we find that ownership concentration affects profitability significantly negatively. However, this result significantly depends on both stock market exposure and the location of control rights.

\section{The Governed Corporation and Profitability}

The major concern in the debate on the separation of ownership and control is whether managers of widely-held corporations pursue their own interests (pet projects, empire building, perks etc.) rather than maximizing shareholder value. Managers may not be adequately controlled by shareholders because monitoring managers is expensive for an individual shareholder if he only commands a negligible share in the firm. An extensive literature has discussed the pros and cons of separating ownership from control. ${ }^{9}$ Most recently, the market-based system of corporate governance has again been seriously questioned by prominent scholars such as Porter (1992), Jensen (1993), Roe (1994b), or Pound (1995) arguing for more shareholder activism. 


\subsection{The governed vs. the managed corporation}

A corporation with free-wheeling managers in charge of decision-making and, more or less, controlling themselves is very much the image of the manager-controlled or managed corporation Pound (1995) contrasts with the so-called governed corporation which he praises as the ideal governance model for restructuring not only corporate America.

The main difference between managed and governed lies in the role the owners of a company play in monitoring and disciplining the management. The managed corporation is characterized by a clear separation of control and ownership. Senior management is in charge of decision-making. The supervisory board is responsible for selecting and monitoring senior managers, and replacing them in case of bad performance. The shareholders participate only insofar as they can oust the supervisory board in a joint voting effort if the corporation does not perform as expected. However, as monitoring and controlling efforts of any one shareholder benefit all others, the free rider problem makes it expensive and unattractive for a small shareholder to exercise and enforce voting rights. Moreover, coordinating a large number of different shareholders for joint voting is difficult or even impossible. In times of crisis, shareholders may then "prefer a cheap 'exit' to an expensive 'voice'" (Bhide 1994, p. 132). Further, corporate supervisory boards may be inefficient or 'entrenched' monitors. As Warner, Watts and Wruck (1988) find, boards only take action when true performance disasters have already happened. ${ }^{10}$ Thus, Pound $(1995$, p. 92) claims that inadequate governance is inherent to the managed corporation and "allows mistakes to go uncorrected until they become catastrophes".

For a corporation to be governed in the sense of Pound, investors must be different from the investors of a managed corporation. "Active" (Jensen 1993, p. 866) or "relationship" (Thompson 1998, p. 27) investors are called for: investors not selling out quickly in times of trouble because they are convinced that the company is being soundly managed and that their interests and concerns are taken seriously by the management. The emphasis in the model of the governed corporation is not on shareholders monitoring the managers more closely 
than in the managed corporation but on active participation of committed owners in the firm's decision-making process. Active participation means in the first place being involved in selecting the top management and initiating replacements in case of inferior performance. However, for having one's interests and concerns respected, a relationship investor needs to be a large shareholder as well, i.e., he must have sufficient control over the firm's assets. ${ }^{11}$ Only investors who control a substantial part of the voting capital will be able to keep managers from diverting free cash flow into pet projects and force them to distribute profits to shareholders. Pound's image of the governed corporation thus suggests that the stakes in a firm should be concentrated in the hands of only a few shareholders. Implicitly it is claimed that by reintegrating ownership and control corporate performance (profitability, productivity, innovative thrust etc.) is going to be enhanced.

Demsetz (1983) has not been convinced of the arguments put forward by Berle and Means and their followers. He argues that corporate plundering or, in his own words, on-thejob consumption can happen in firms with concentrated ownership as well: "Where is it written that the owner-manager of a closely held firm prefers to consume only at home?" (Demsetz 1983, p. 381) Contesting the model of the firm that implicitly underlies the managerial discretion hypothesis as well as the agency approach, Demsetz states, "It is clearly an error to suppose that a firm managed by its only owner comes closest to the profit-maximizing firm postulated in the model firm of economic theory." (p. 383). For Demsetz, ownership concentration is the endogenous and efficient outcome of a firm's response to its competitive environment. Product market competition forces firms to adopt cost minimizing governance structures, at least in the long run. The competitive market mechanism then eliminates inefficient structures and generates good governance. From Demsetz' perspective, the mode of corporate governance does not affect firm performance but is simultaneously determined with firm performance by the forces of competitive markets.

Shleifer and Vishny (1997, pp. 755) point out that large shareholders can inflict substantial costs on other shareholders in the form of an expropriation-like redistribution of 
wealth if their interests diverge from those of the firms' small shareholders. ${ }^{12}$ Furthermore, Mayer (1996, p. 12) is concerned that a close relationship between large shareholders and managers may prevent these large investors from taking necessary action in situations, "where investors' reputations may suffer as a consequence of attempts to dismiss management".

As argued by Cubbin and Leech (1983), the location of control rights may be a more important determinant of the degree of control to be exerted by owners than the degree of ownership concentration. Internal control, or 'insider' control (Mayer 1996), may represent a higher degree of control at any given level of blockholdings than external, or 'outsider', control. Family interests, allied industrial firms, banks, and holdings companies are understood as 'insiders', while the shareholders of diffusely held firms are seen as 'outsiders'. In addition, differences in commitment to a firm may emerge between individuals or families as owners (who often are the company founders) and ownership by industrial firms or financial institutions. Therefore, the location of control rights, respectively the identity of owners, may matter even more. Under the German system of corporate governance with its high ownership concentration, large shareholders may be the insiders or committed investors imagined by Pound and others, exercising internal control by sitting on supervisory boards or by posing the CEO.

To sum up, the debate on the managed versus the governed corporation, or the insider versus the outsider model of the corporate governance, has generated conflicting hypotheses concerning the link between ownership, control, and firm performance. The argumentation of Pound and others implies that the governed, or tightly-held, firm outperforms the managed, or diffusely-held firm, whereas Demsetz suggests that corporate governance in itself does not matter. Cubbin and Leech point to the identity of owners as a more important governance indicator. The cost arguments of Shleifer and Vishny as well as Mayer suggest that there may be a trade-off between the degree of governance exerted and advantages in corporate performance. It is thus up to empirical research to test the validity of the advanced hypotheses. 


\subsection{Empirical evidence}

The existing empirical evidence refers almost exclusively to the Anglo-Saxon countries and does not allow for clear-cut answers. Short (1994, p. 227) concludes that the studies surveyed by her "do not provide conclusive evidence either in support of, or in opposition to, the hypothesis that the ownership and control structures of firms materially affect their performance." Mayer (1996, p. 17) interprets the empirical evidence as implying that there are "benefits in the exercise of corporate governance from modest levels of concentrations of ownership", but that at high levels of ownership concentration "exploitation of private benefits" may result.

Despite differences in corporate governance systems have been highlighted to potentially translate into profitability differences, only a few empirical studies have investigated the potential impact of governance indicators on performance for German firms. In a pioneering study, Thonet and Poensgen (1979) found significantly lower returns on equity for ownercontrolled than for manager-controlled quoted stock corporations. A firm was defined as ownercontrolled if individuals or families held at least the blocking minority (25\% plus one vote of the voting capital). The major deficiency of the study is that ownership structures were identifiable only for about 90 of the 300 firms. Thus in the regression analysis owner-controlled firms had to be compared to a mixture of presumably manager-controlled firms and firms with unknown governance structures, rendering the results questionable.

The studies of Cable (1985), Schmid (1996), Chirinko and Elston (1996), and Weigand (1999) focused on banks as blockholders in industrial firms. Cable (1985) employed a very small sample of 48 stock corporations from Germany's 100 largest corporations in 1970. The cross-section regression for the time period 1968 to 1972 yielded a significantly positive impact of bank involvement on profitability. A similar result is reported by Schmid (1996) for the years 1974 and 1985. Chirinko and Elston (1996) explored the long-run relationship between bank control and firm performance for 300 stock corporations over the observation period 1965 to 1990. Bank control was defined by different dichotomous variables indicating blockholdings of banks or accumulated proxy voting rights. The coefficients of these indicator variables were 
insignificantly negative in cross-sectional OLS-regressions with return on total assets as dependent variable. However, as in the Thonet and Poensgen study, detailed ownership information was only available for subsets of the sample. Weigand (1999) applied a more comprehensive data set which includes detailed ownership data (identity of owners, outstanding shares) for 240 stock corporations in each year of the observation period 1965 to 1986 . On average (and in the long-run), bank-owned and family-owned firms were found to have significantly higher returns on total assets than the group of presumably manager-controlled (managed in the sense of Pound) firms.

Franks and Mayer (1997) analyzed a panel data set of 171 quoted corporations over the period 1989 to 1994 . Using a fixed effects panel regression approach, they could not establish a significant impact of ownership variables or turnover of blockholdings on firm performance. There was only weak evidence of a relationship between either management or supervisory board turnover and performance in firms with concentrated ownership. This result is consistent with Kaplan's (1994) findings. Franks and Mayer interpret their results as lending no support to the view that the market in share stakes performs a disciplining function in Germany. Rather, concentration of ownership may be "used to extract private benefits rather than wider shareholder interests" (1997, p. 17).

Gedajlovic and Shapiro (1998) studied the blockholdings-performance link for the largest firms from five major industrialized countries. For the 99 publicly traded German stock corporations incorporated in their sample they estimated a significantly negative and nonlinear impact of ownership concentration (measured by the percentage of shares outstanding held by the largest shareholder) on the return on total assets over the period 1986 to 1991. Thus profitability first decreases in ownership concentration and then, at higher levels of concentration, rises again. ${ }^{13}$ Goergen (1999) focussed on German IPOs. In both static and dynamic panel data regressions, ownership concentration did not have any impact on profitability (measured by cash flow over total assets) for the 86 IPOs observed over the period 1981 to 1988. Goergen interpreted his results as supporting the Demsetz hypothesis that 
ownership structure is chosen as to maximize firm value. Becht (1999) explored the impact of ownership concentration on liquidity, as measured by the ratio of turnover to market capitalization, among the companies included in the DAX100 index in 1996 to 1998. He found a significantly negative effect of concentrated blockholdings.

\section{Ownership Concentration, Insider Control, and Firm Performance An Empirical Analysis of German Corporations}

Rather than being a matter of technical explanations (small samples, cross-section vs. panel regressions etc.) the conflicting results for Germany may reveal that the relationship between ownership and profitability has changed over the decades examined. A significant positive relationship seems to have existed for "governed" (owner-controlled) firms during the 1970s and early 1980s (Cable, Schmid, Weigand), whereas the relationship vanishes or is even inverse when the late 1980s and the 1990s are included (Becht, Chirinko and Elston, Franks and Mayer, Goergen, Gedajlovic and Shapiro). The opening of markets and increased international competition may have altered the profitability-ownership concentration relation since the late 1980s. To explore this conjecture we will study the ownership-profitability issue using a large panel data set for the 1990s. To control for the importance of stock market exposure, we have included non-quoted stock corporations as well as limited liability companies.

\subsection{Data, variables, and sample characteristics}

The data set used in the subsequent analysis contains 361 firms from the German mining and manufacturing industries. The time period covered is 1991 to 1996, which yielded the largest number of reporting firms with complete and consistent data. The balance sheet and profit-andloss information originates from three different sources: the Hoppenstedt Bilanzdatenbank, a commercially sold data source, the Bundesanzeiger, a federal gazette (Amtsblatt), in which 
corporations are obliged by law to publish their annual financial statements, as well as annual reports directly obtained from the corporations. We referred to the Bundesanzeiger or requested annual reports from firms to double-check and correct deficiencies in the Hoppenstedt Bilanzdatenbank (inconsistencies in reporting, missing values, obviously wrong entries etc.). We used unconsolidated company data whenever available and excluded pure holding companies. The sample firms can be classed as belonging to 30 different two-digit industries, among them machinery (76 firms), chemicals \& pharmaceuticals (60 firms), the electronic products industry (56 firms), and iron \& steel (37 firms). Most of the firms have the legal form of stock corporations (Aktiengesellschaften, 300 companies). Only 183 of these stock corporations were officially listed and traded on German stock exchanges during the observation period. In addition to stock corporations also some limited liability corporations ('GmbH', 54 firms) as well as limited commercial partnerships ('GmbH \& Co. $\mathrm{KG}^{\prime}$ ', $\mathrm{KGaA}$ ', 7 firms) for which detailed balance sheet data were available could be included.

In this study, we use the return on total assets (ROA) as an indicator of corporate performance. In the descriptive tables we will also report the return on equity (ROE). Our preferred measure of firm performance is however ROA, since ROE comparisons across firms may be distorted by the leverage effect and differences in the user cost of capital. In either case, the nominator of ROA and ROE is gross profits, calculated from firms' profit-and-lossstatements as sales revenue minus expenses for personnel and materials. This definition is equivalent to earnings before interest, taxes, and depreciation. Equity capital is defined as shareholders' equity plus reserves, which also include pension liabilities. Pension liabilities are added for two reasons. First, it is peculiar to the German system of accounting that pension assets and pension liabilities are not netted out in companies' balance sheets. Further, pension liabilities are not paid into a trust (pension fund) but remain within the firm. They are available to the firm as a source of internal long-term finance. Pension liabilities thus can be seen as 'quasi' equity. Second, the shareholders' equity of limited liablity companies $(\mathrm{GmbH})$ is, by legal construction, extremely low. Adding reserves and pension liabilities to shareholders' equity helps 
avoid generating unrealistically high returns on equity for these firms compared to stock corporations.

To identify owners, share distributions, and composition of managing and supervisory boards we used investors' handbooks on German companies edited by two German commercial banks, Commerzbank and the former Bayerische Hypotheken- und Wechselbank (now Hypo-Vereinsbank), as well as by a commercial publisher, Hoppenstedt. The handbooks are Commerzbank's Wer gehört zu wem? (Who owns whom?, issues 1988, 1990, 1992, 1994), Bayerische Hypotheken- und Wechselbank ("Hypo-Guide") Wegweiser durch deutsche Aktiengesellschaften (Guide of German Stock Corporations, annual issues 1988-1996), and Hoppenstedt's Börsenführer (annual issues 1988-1996). In combining these data sources it was possible to obtain a rather precise picture of voting stock ownership. In particular, in many cases the Hypo-Guide also lists blocks smaller than $25 \%$ and indicates indirect ownership (voting rights granted to a large shareholder from others shareholders). Sometimes even very small blockholdings (below 5\%) are reported. For the purposes of this study, we have defined a 'large' shareholder as one who controls at least 5 per cent of a firm's voting capital. This cut-off point of when a shareholder is large rather than small is not of so much relevance as it is in Anglo-Saxon studies $^{14}$, since almost all firms have large shareholders who control at least 25 percent of the voting capital. As Table 1 shows, $65 \%$ of the companies in the sample have one large shareholder who, on average, controls $89 \%$ of the voting stocks and faces a group of small shareholders with an aggregated share in the voting capital of $11 \%$.

The degree of ownership concentration is the standard measure used in the empirical literature to account for the extent of "governance" exercised by the owners of a firms. In this study as in previous ones, ownership concentration is measured by the Herfindahl index of outstanding voting stock and, alternatively, by the percentage stake of the largest shareholder. The share of the largest shareholder indicates her fundamental voting power, that is, the ability to outvote other shareholders or initiate major changes by herself (e.g., ousting the supervisors, introduce a new corporate charter). The Herfindahl index, defined as the sum of squared 
individual stakes, has the advantage of accounting for an asymmetric dispersion of shares among different shareholders. ${ }^{15}$

Ownership concentration may not suffice as an indicator of the degree of "governance". The identity of owners may play a more crucial role. As discussed in more detail in Becht and Boehmer (1997) as well as Boehmer (1999), officially reported shareholdings may not reflect the true extent of voting control exercised by owners. Complex cross-shareholding arrangements and unreported fiduciary and dormant voting rights complicate the identification of actual controllers. Nevertheless, given the information available, we attempt to assess the relevance of the owners' identity on the link between profitability and ownership concentration. For grouping the sample firms according to the location of control rights five broad categories of direct owners can be identified: another industrial firm or holding company (INDFIRM), families or (voting pools of) individuals (FAMILY), financial institutions (banks or bank-owned investment companies, insurance companies) (FININST), different large shareholders (MIX, e.g. industrial firms and investment companies), and foreign owners (FOREIGN). A sixth group, CHANGE, is defined to account for 26 firms for which a turnover of blockholdings from one of these owner categories to another was observed during the observation period. For example, if an industrial firm sold its stake in a firm completely to another industrial firm we treated such a transfer of shareholdings not as a change in the location of control rights, since the new owner again belonged to the same owner category. If, however, the owning industrial firm sold only part of its holdings to another industrial firm so that the new co-owner could be seen as an additional large shareholder we counted such a transfer as "change" (from INDFIRM to MIX). The groups are mutually exclusive, that is, a firm that had as an identified shareholder, for example, another industrial firm in some years and a bank in other years only appears in the CHANGE group but not in the groups INDFIRM or FININST. Due to the lack of detailed owner information, the foreign-owned firms were also treated as a separate sub-group. A few firms are owned by foundations which have no owner in a strict sense. It is thus unclear who really controls decisions. However, since these foundations are close to the founding families of these 
firms, as in the case of Bosch $\mathrm{GmbH}$ (a leading electronic products firm), it is not unreasonable to classify them to the group of firms controlled by families or voting pools of individuals. The group of firms with widely dispersed shareholdings seems to be missing. We have 15 stock corporations in the sample for which more than $75 \%$ of voting capital is dispersedly held. The following firms from our sample can be seen as "widely dispersed" (average aggregated share of dispersed holdings 1991-96 in brackets): Bayer (92.00\%), Mannesmann (100.00\%), Schering (92.80\%), Siemens (91.70\%), and VEBA (96.70\%). However, the study of Baums and Fraune (1995) shows that in the 1992 annual shareholders' meetings banks controlled an aggregate of more than $90 \%$ of these firms' voting capital via associated investment companies and proxy votes. The firms were therefore added to the group of firms with financial institutions as largest shareholders. However, since this information on aggregated proxy voting rights was only available for one year we have not used it in the calculation of the Herfindahl-index itself but rather as qualitative information for classifying firms. Table 2 gives the details of the group definitions and examples of firms classified as well as definitions of all other variables used in this study.

\section{Table 2 about here}

To relate back to Pound's argument of the managed vs. the governed firm as well as the insider vs. outsider-distinction, corporations having individuals or families (FAMILY), financial institutions (FININST), or different independent large shareholders (MIX) may be interpreted as potentially governed by committed insiders. By contrast, for firms owned by another industrial firm or holding company (INDFIRM) it might be hired managers rather than ultimate owners who control the managers of the owned company. Most of the firms of this group were majority-owned by one of the following large quoted stock corporations: BASF (90\% dispersed holdings), Bayer (92\%), Daimler-Benz (32\%), Dt. Babcock (100\%), KruppHoesch (14\%), MAN (70\%), Mannesmann (100\%), Preussag (48\%), Siemens (92\%), Thyssen 
(66\%), or VEBA $(97 \%)$. The firms from the INDFIRM group could then be considered as potentially managed, since the largest shareholder tends to be - at least for German standards - a dispersedly held large stock corporation. However, we make no attempt here to argue that a certain location of control rights indeed implies "more"or "less" effective governance. Without conducting in-depth case studies on each firm a case for insiders as owners to be more "committed" or "active" investors can hardly be made. It is therefore not entirely clear whether these owners really "govern", or whether hired managers nonetheless exercise control even if ownership concentration is high and firms are owned by families, for example.

To investigate whether stock market exposure makes a difference for the potential link between governance indicators and corporate performance we distinguish between corporations traded on the stock exchange (QUOTED) and non-traded or non-stock corporations (NON-QUOTED).

Table $3 \mathrm{~A}$ presents the mean and median values of selected variables for the full sample and the sub-samples of quoted and non-quoted firms. Comparing the groups of quoted and non-quoted firms, the last column reports statistics of testing the hypotheses of equal group means (t-statistic) and medians (Mann-Whithney statistic). Quoted firms have significantly higher average returns on total assets and also higher median returns on equity. The quoted firms are less levered. Further, as measured by sales, employment, and the log of total assets, the quoted firms are substantially larger on average but the median firms do not differ significantly in sales or total assets. Finally, quoted firms realized significantly higher growth of turnover than non-quoted firms.

\section{Table 3A about here}

Table 3B contains descriptive statistics of selected variables for the subgroups of firms classified by the identity of the largest owner. For any pair of subgroups and the variables listed in Table 3B we also conducted pairwise t- and median tests not reported here separately. ${ }^{16}$ 
The tests reveal that the INDFIRM firms have significantly lower rates of return than any other subgroup except for the equity return of firms controlled by financial institutions. Ownership concentration is the highest for the managed firms. Family-controlled firms have the highest ROE and the second highest ROA but their share of equity capital is the lowest of all groups. Bank-controlled firms have the highest share of equity capital and thus the lowest degree of leverage. Foreign-owned firms have the highest ROA and the second highest ROE.

\section{Table 3B about here}

\subsection{Regression model and hypotheses}

To investigate the impact of the mode of corporate governance on corporate performance we use the following empirical model consisting of two panel regression equations

$$
R O A_{i t}=b_{1} O C_{i t}+b_{2} B_{i t}+b_{3} S_{i t}+b_{4} G_{i t}+b_{5} K_{i t}+b_{6} C_{i, t-1}+b_{7} H_{i t}^{j}+a_{i}+\lambda_{t}+\varepsilon_{i t},
$$

$$
O C_{i t}=d_{1} R O A_{i t}+d_{2} B_{i t}+d_{3} S_{i t}+d_{4} G_{i t}+d_{5} N_{i t}^{L S}+d_{6} C_{i, t-1}+d_{7} H_{i t}^{j}+a_{i}+\lambda_{t}+\varepsilon_{i t}
$$

in which the subscript $i=1, \ldots, 361$ identifies individual firms, $j=1, \ldots, 30$ indicates the respective two-digit industry, and $t=1992, \ldots, 1996$ denotes time periods.

In regression (1), the return on total assets, $R O A$, is regressed on ownership concentration $O C$ and a set of other variables. For lucidity and space restrictions we will only present results using the unbounded Herfindahl index as in Demsetz and Lehn (1985). ${ }^{17} B$ indicates the presence of the largest shareholder on the executive board. The following variables, well-known from the industrial organization literature on the determinants of profitability, serve as right-hand side control variables: absolute firm size $S$ (natural logarithm of total assets), firm 
growth $G$ (logarithmic annual change in turnover), capital intensity $K$ (tangible assets divided by the number of employees), capital structure $C$ (shareholders' equity plus reserves divided by total capital), and the Herfindahl index of supplier concentration at the two-digit industry level (source: German Statistical Office). These variabes will be discussed in more detail below. The regression equation further includes firm-specific effects $a_{i}$, time-specific effects $\lambda_{t}$, and a classical regression error term $\varepsilon_{i t}$. The firm- and time-specific effects are supposed to control for systematic variation in profitability not captured by the independent variables (e.g., differences in risk taking or in the cost of capital). ${ }^{18}$

As hypothesized by Demsetz, in active and well-functioning markets for corporate control rights ownership concentration and profitability should be simultaneously determined. To test for simultaneity bias in regression equation (1) we "endogenize" ownership concentration in regression equation (1) and estimate (1) and (2) by applying standard instrumental variable techniques (2SLS). As theory is still rather silent on potential determinants of ownership concentration, regression equation (2) is an ad-hoc specification. ${ }^{19}$ In the reducedform regression we regress ownership concentration on all other right-hand side variables in (1) plus the number of large shareholders, $N^{L S}$. In the second-stage regression, we employ in (1) and (2) the fitted values of OC and ROA from the reduced-form regressions instead of their observed values. To identify the two-equation system capital intensity is excluded from (2), while the number of large shareholders is excluded from (1) in the second-stage regressions. ${ }^{20}$

Our main interest lies in estimating the coefficients $b_{1}$ and $b_{2}$. If ownership concentration indicates tighter and performance-enhancing governance exerted by owners, $b_{1}>0$ is to be expected. If the Demsetz-Lehn hypothesis is valid, $b_{1}=0$ should be found. By contrast, $b_{1}<0$ may indicate inefficiency or rent extraction due to the presence of large shareholders. The same argumentation holds for the presence of the largest shareholder on the executive board.

For the impact of firm size and firm growth on profitability economic theory offers no clear-cut predictions. The economies of scale and scope argument, as advanced e.g. by 
Baumol (1959), implies a positive effect of absolute firm size. Organizational inefficiencies (Xinefficiency) and also lower risk premiums because of diversification could render $b_{3}$ negative. ${ }^{21}$ Firm growth may, on the one hand, reflect better investment opportunities that allow for a higher profitability, implying $b_{4}>0$. On the other hand, managers could indeed have sufficient discretion to divert free cash flow and overinvest so that profitability decreases in firm growth, $b_{4}<0$. The coefficient on capital intensity may help to identify overinvestment. If decreasing scale economies prevail, profitability should decrease in capital intensity, $b_{5}<0$. However, capital intensity may indicate barriers to entry and exit, as frequently assumed in the IO literature, which allow incumbent firms to earn rents. The coefficient of capital intensity should then be positive. With imperfect capital markets capital structure matters for investment decisions and firm profitability. Depending on informational asymmetries, transaction costs, and growth prospects capital structure choices will vary across firms and industries. If a higher equity share implies a lower risk of bankruptcy, an inverse relation between profitability and the share of equity capital, $C$, can be expected, $b_{6}<0$, since the return on investment compensating for risk-taking decreases in risk. To reduce potential simultaneity bias $C$ is lagged by one period. ${ }^{22}$ Supplier concentration is implied by oligopoly theory to be positively correlated with profitability. An extensive empirical literature has examined, and overwhelmingly supported, the positive profitability-concentration relation. ${ }^{23}$ We therefore expect $b_{7}>0$. As it is not the concern of this paper to discuss the appropriate interpretation of the relationship, we take market concentration as a summary measure of industry characteristics, reflecting technology (potential scale economies), demand (price elasticity) as well as the intensity of competition.

The regression equations are estimated using a GLS panel estimator described in Hsiao (1986, pp. 55) which allows for heteroskedasticity and first-order serial correlation of the regression residuals. ${ }^{24}$ Standard specification tests for panel data regressions are employed to test for the presence of fixed effects ("Hausman test", Hausman 1978), heteroskedasticity (Lagrange multiplier test, Breusch and Pagan 1980), and first-order serial correlation (modified DurbinWatson test, see Bhargava, Franzini, and Narendanathan 1982). 


\subsection{Results}

\section{Ownership concentration, stock market exposure, and profitability}

Table 4A contains the coefficient estimates for the profitability regression. Column 1 reports the regression coefficients using the full sample of firms. Column 2 presents the estimates for the quoted firms, while column 3 gives the coefficient differences with respect to the (not separately reported) regression coefficients of the non-quoted firms. Ownership concentration affects ROA significantly negative. This negative impact of ownership concentration is somewhat weaker for the quoted $(-0.0024)$ than for the non-quoted firms $(-0.0051)$ but the coefficient difference $(-$ 0.0031 ) is not statistically significant. The coefficient on board representation of the largest shareholder is insignificantly negative (and remains so when ownership concentration is excluded from the regressions). Larger firms and firms with a higher share of equity capital (lower leverage) have significantly lower returns, which is consistent with risk-return considerations. Firm growth and market concentration affect ROA positively. Firm-specific effects are highly significant, implying that there are systematic firm-specific influences not captured by the included right-hand side variables. Time-specific effects are insignificant as long as capital intensity is included in the regression but become highly significant when capital intensity is excluded. Our measure of capital intensity thus seems to pick up cyclical effects (capital utilization). The Hausman test confirms that the firm- and time-specific effects are fixed (constant) rather than random(ly distributed across firms).

\section{Tables 4A and 4B}

Table 4B summarizes for the full sample the results from assuming that profitability and ownership concentration are simultaneously determined. Columns 1 and 2 contain the reduced-form (first-stage) and second-stage estimates for the profitability regression (1), columns 3 and 4 the respective estimates for the ownership concentration regression (2). 
Regarding the profitability regression, endogenizing ownership concentration does not change any of the results of Table 4A. The same holds true for distinguishing between quoted and nonquoted firms, not reported here separately. The test statistic of the Wu-Hausman is low and insignificant at any conventional level of significance, indicating that there is no simultaneity bias in the profitability regression. In other words, ownership concentration can be taken as exogenous with respect to profitability. Ownership concentration is significantly lower for firms which are larger, use more capital per employee, and have more equity capital. By contrast, growing firms and firms operating under more concentrated market structures have more concentrated ownership structures. ROA affects ownership concentration negatively but the $\mathrm{Wu}$ Hausman test statistic is highly significant so that there is simultaneity bias. Therefore, ROA cannot be assumed exogenous in the ownership concentration regression.

\section{The Identity of Owners}

Considering the location of control rights Table $5 \mathrm{~A}$ gives some new insights. ${ }^{25}$ The group of firms owned by another industrial firm, INDFIRM, is taken as the base group. Column 1 presents the regression coefficients for this base group, whereas the following columns contain the estimates of coefficient differences with respect to the other groups of owners. The coefficient on ownership concentration is positive but insignificant for the INDFIRM firms. For these firms, which might be managed rather than governed, ownership concentration has no systematic effect on ROA. The negative impact of ownership concentration found for the full sample of firms can be traced back to the firms owned, and possibly governed, by FAMILY and MIX. For the MIX firms the negative coefficient suggests that larger asymmetries in shareholders' stakes translate into lower profitability. In other words, the presence of a strong second or third large shareholder enhances profitability. A negative but insignificant effect also turns up for the firms owned by foreigners and the firms that experienced a change in owners. Ownership concentration makes a significantly positive difference for firms potentially governed by financial institutions. In this group of firms ownership concentration is by far the lowest (see 
Table 3B). By German standards, these firms can almost be defined as "dispersedly held". Finally, Table 5B extends the analysis to taking stock market exposure into account. Now it becomes clear that the negative ownership concentration effect results particularly from the nonquoted firms owned by families (individuals, foundations) or foreigners but also from quoted firms which have different large shareholders.

\section{Summary and conclusion}

Almost a decade ago Michael C. Jensen (1993, p. 873) has set out the research agenda for the new millenium in the field of corporate governance, corporate finance, and corporate performance:

For those with a normative bent, making the internal control systems of corporations work is the major challenge facing economists and management scholars in the 1990s. For those who choose to take a purely positive approach, the major challenge is understanding how these systems work, and how they interact with other control forces (in particular the product and factor markets, legal, political, and regulatory systems, and the capital markets) impinging on the corporation.

This paper contributes to the positive approach. We focused on German firms because ownership concentration is an important feature setting the German system of corporate governance apart from the Anglo-Saxon. In the corporate governance literature ownership concentration is often understood as reflecting a stronger governing effort of owners. By reducing informational asymmetries between owners and managers as well as between the firm and external investors ownership concentration is expected to affect firm profitability positively. Contrary to this argument, we find a significantly negative impact of ownership concentration on profitability as measured by the return on total assets. 
Ownership concentration can be an insufficient or misleading indicator of the control that owners actually exert. We therefore checked further governance indicators. Representation of the largest shareholder on the board of executive directors did not turn out to make a significant difference for profitability. However, the profitability-ownership concentration relation depends on both stock market exposure and the location of control rights. The negative effect of ownership concentration could be traced back to family- or foreign-owned non-quoted firms as well as quoted firms with different large shareholders. A positive impact of ownership concentration on profitability, supportive of managerial discretion and agency theories, showed up for quoted firms which have financial institutions as large shareholders. Further, simple group comparisons of mean and median profitability (ROA, ROE) imply that stock market exposure is profitability-enhancing.

Finally, we have to answer the question posed in this paper: Does the governed corporation perform better? If one is willing to view firms owned by families, financial institutions, or a mix of large shareholders as (potentially) governed rather than managed, the answer to the question seems to be yes. These groups had significantly higher mean and median profitabilities than the group of firms owned by another industrial firm. These results raise more questions than they answer. First, why are profitability differences between the group of firms owned by another industrial firm and all other groups so pronounced? Do the owning firms extract rents by e.g. charging high transfer prices from the owned firms? Second, significant profitability differences also exist between the different groups of firms that may be governed. What cuases these differences? Third, industry characteristics such as the underlying technology and knowledge conditions may simultaneously determine governance structures, investment, and profitability. ${ }^{26}$ In industries such as optical instruments or machinery, production technology and the knowledge on which firm know-how is based does not require large firm sizes per se, that is, cost advantages (scale economies) from large-scale operations (production, R\&D) are not ubiquitous. Therefore, these industries offer a favorable environment for smaller firms, and indeed that is where we find small family-owned firms to be very common. By contrast, in the 
chemical and pharmaceutical industry stock corporations dominate. Clearly, production technologies require large firm sizes. Different ownership structures are also necessary to satisfy the increased capital needs and to spread the higher risk involved in large-scale operations. To get a more comprehensive picture of the impact of governance structures on firm performance, future research should focus on the link between industry characteristics, firm financing, investment, and profitability.

In sum, our study finds systematic influences of ownership concentration, stock market exposure, and the location of control rights on the profitability of German corporations. Our main results imply that (1) the presence of large shareholders does not necessarily enhance profitability, and (2) concentrated ownership might be a sub-optimal choice for many of the tightly held German corporations. 


\section{References}

Audretsch, D.B. and Elston, J.A. (1997): Financing the German Mittelstand, Small Business Economics 9, 97-110.

Audretsch, D.B. and Weigand, J. (1999): Does Science Make a Difference? Investment, Finance and Corporate Governance in German Industries, Working paper No. 2056, London: CEPR.

Baltagi, B.H. (1995): Econometric Analysis of Panel Data, New York et al.: Wiley.

BAUMOL, W. (1959): Business Behavior, Value, and Growth, New York: Macmillan.

BAums, T. and Fraune, C. (1995): Institutionelle Anleger und Publikumsgesellschaft: Eine empirische Untersuchung, Die Aktiengesellschaft 40, 97-112.

BAuMS, T. (1996): Corporate Governance Systems in Europe - Differences and Tendencies of Convergence, Crafoord Lecture, Working Paper No. 8/96, University of Osnabrück.

Becht, M. (1999): European Corporate Governance: Trading Off Liquidity against Control, European Economic Review 43, 1049-1056.

Becht, M. and BoEHMER, E. (1997): Transparency of Ownership and Control in Germany, Working paper, Berlin: Humboldt University.

Bergloef, E. (1997): Reforming Corporate Governance: Redirecting the European Agenda, Economic Policy, 93-123.

Berle, A. and Means, G. (1932): The Modern Corporation and Private Property, New York: MacMillan.

Bhargava, A., L. Franzini and W. NARENDANATHAN (1982): Serial Correlation and the Fixed Effects Model, Review of Economic Studies 49, 533-549.

BhIDE, A. (1993): The Hidden Costs of Stock Market Liquidity, Journal of Financial Economics 34, 31-51.

BHIDE, A. (1994): Efficient Markets, Deficient Governance, Harvard Business Review, November-December, 129-139.

BlaIR, M. (1995): Ownership and Control: Rethinking Corporate Governance for the TwentyFirst Century, Washington D.C.: The Brookings Institution.

BOEHMER, E. (1999): Who controls Germany? An exploratory analysis, Working paper, Berlin: Humboldt University.

Brealey, R. and Myers, S. (1984): Principles of Corporate Finance, $2^{\text {nd }}$ edition, New York et al.: Mc Graw-Hill.

Breusch, T. and Pagan, A. (1980): A Simple Test for Heteroscedasticity and Random Coefficient Variation, Econometrica 47, 1287-1294.

Bolton, P. and von THADDEN, E.-L. (1998): Liquidity and Control, Journal of Institutional and Theoretical Economics 154, 177-215. 
Burkhart, M., Gromb, D. and Panunzi, A. (1998): The Choice of Ownership Structure: Agency costs, Monitoring, and the Decision to Go Public, Quarterly Journal of Economics $112,693-728$.

CABle, J. (1985): Capital Market Information and Industrial Performance: The Role of West German Banks, Economic Journal 95, 118-132.

Chirinko, R. and Elston, J.A. (1996): Finance, Control, and Profitability: An Evaluation of German Bank Influence, American Institute for Contemporary German Studies: The Johns Hopkins University, Working Paper No. 28, Washington, D.C.

Cubbin, J. and LEECH, D. (1983): The Effect of Shareholding Dispersion on the Degree of Control in British Companies: Theory and Evidence, Economic Journal 93, 351-369.

Demsetz, H. (1983): The Structure of Ownership and the Theory of the Firm, Journal of Law \& Economics 26, 375-390.

DemsetZ, H. and LEHN, K. (1985): The Structure of Corporate Ownership: Causes and Consequences, Journal of Political Economy 93, 1155-1177.

EDWARDS, J. and FISCHER, K. (1994): Banks, Finance, and Investment in Germany, Cambridge: Cambridge University Press.

FAMA, E. (1980): Agency Problems and the Theory of the Firm, Journal of Political Economy $88,288-307$.

FAMA, E. and Jensen, M. (1983): Separation of Ownership and Control, Journal of Law and Economics 26, 301-325.

FrANKEL, A. and PALMER, D. (1996): The Management of Financial Risks at German Nonfinancial Firms: The Case of Metallgesellschaft, American Institute for Contemporary German Studies: The Johns Hopkins University, Working Paper No. 18, Washington, D.C.

FRANKS, J. and MAYER, C. (1997): Ownership, Control and the Performance of German Corporations, Paper presented at the Center for Financial Studies Conference, November 19-20, Frankfurt a.M.

GedAJlovic, E. and ShapIRO, D. (1998): Management and Ownership Effects: Evidence from Five Countries, Strategic Management Journal 19, 533-553.

Goergen, M. (1999): Corporate Governance and Financial Performance, Cheltenham: Edward Elgar.

Hall, M. and WeISS, L. (1967): Firm Size and Profitability, Review of Economics and Statistics 47, 319-331.

HaUSMAN, J.A. (1978): Specification Tests in Econometrics, Econometrica 46, 1251-1272.

Hopt, K., Kanda, H., Roe, M.J., Wymersch, E. and PRIGGe, S. (1998): Comparative Corporate Governance: The State of the Art and Emerging Research, Oxford: Clarendon Press.

HsiaO, C. (1986): Analysis of Panel Data, Cambridge: Cambridge University Press.

Jensen, M.C. (1986): Agency Costs of Free Cash Flow, Corporate Finance and Takeovers, American Economic Review 76, 323-329. 
Jensen, M.C. (1988): Takeovers: Their Causes and Consequences, Journal of Economic Perspectives 2, 21-48.

JENSEN, M.C. (1993): The Modern Industrial Revolution, Exit, and the Failure of Internal Control Systems, Journal of Finance 48, 831-880.

Jensen, M.C. and Meckling, W. (1976): Theory of the Firm: Managerial Behavior, Agency Costs, and Capital Structure, Journal of Finanical Economics 3, 305-360.

Jensen, M.C. and RubACK, R. (1983): The Market for Corporate Control: The Scientific Evidence, Journal of Financial Economics 11, 5-50.

KaPlan, S. (1994): Top Executives, Turnover, and Firm Performance in Germany, Journal of Law, Economics, and Organization 10, 142-159.

Keasey, K., Thompson, S. and Wright, M. (1997): Corporate Governance: Economic, Management, and Financial Issues, Oxford: Oxford University Press.

MARRIS, R. (1964): The Economic Theory of Managerial Capitalism, Glencloe: Free Press.

MARTIN, S. (1993): Advanced Industrial Economics, London: Blackwell.

MAYER, C. (1996): Corporate Governance, Competition, and Performance, OECD Economic Studies 27, 7-34.

MAYER, C. (1998): Financial Systems and Corporate Governance: A Review of the International Evidence, Journal of Institutional and Theoretical Economics 154, 144-165.

MonKs, R. and Minow, N. (1995): Corporate Governance, New York: Blackwell Publishers.

OECD (1999): Principles of Corporate Governance, Paris: OECD.

PAGANo, M. and RöEll, A. (1998): The Choice of Ownership Structure: Agency costs, Monitoring, and the Decision to Go Public, Quarterly Journal of Economics 113, 187-225.

Perlitz, M. and Seger, F. (1994): The Role of Universal Banks in German Corporate Governance, Business and the Contemporary World 4.

Perlitz, M. and Seger, F. (1995):When Banks and Business Make Bad Bedfellows, The Wall Street Journal Europe, April 4.

Porter, M.E. (1992): Capital Disadvantage: America's Failing Capital Investment System, Harvard Business Review, September-October, 65-82.

Pound, J. (1995): The Promise of the Governed Corporation, Harvard Business Review, MarchApril, 89-98.

RAJAN, R. and ZINGALES, L. (1998): The Governance of the New Enterprise, Working paper, University of Chicago.

RoE, M. (1994a): Strong Managers, Weak Owners: The Political Roots of American Corporate Finance, Princeton: Princeton University Press.

RoE, M. (1994b): Some Differences in Corporate Governance in Germany, Japan, and America, in Baums, T. et al. (eds.): Institutional Investors and Corporate Governance, Berlin, New York: Springer Verlag. 
SCHERER, F.M. and Ross, D. (1990): Market Structure and Economic Performance, Boston: Houghton Mifflin.

SCHMID, F.A. (1996): Banken, Aktionärsstruktur und Unternehmenssteuerung, Kredit und Kapital 29, 402-427.

SCHNITZER, M. (1997): Short-Termism and the Market for Corporate Control, in Picot, A. and Schlicht, E. (eds.): Firms, Markets, and Contracts, Heidelberg: Springer Verlag.

SHLEIFER, A. and ViSHnY, R.W. (1986): Large Shareholders and Corporate Control, Journal of Political Economy 95, 461-488.

SHLEIFER, A. and VisHNY, R.W. (1997): A Survey of Corporate Governance, Journal of Finance $52,737-783$.

ShORT, H. (1994): Ownership, Control, Financial Structure, and the Performance of Firms, Journal of Economic Surveys 8, 203-249.

Thompson, J.K. (1998): Shareholder Value and the Market for Corporate Control in OECD Countries, OECD Financial Market Trends 69, February, 15-37.

Thonet, P.J. and PoensGen, O. (1979): Managerial Control and Economic Performance in West Germany, Journal of Industrial Economics 28, 23-37.

WARner, J., WatTs, R. and Wruck, K. (1988): Stock Prices and Top Management Changes, Journal of Financial Economics 20, 461-492.

WeIgand, J. (1999): Corporate Governance and Corporate Performance in the Knowledge-based Economy, Working paper, Indiana University.

White, H. (1980): A Heteroscedasticity-Consistent Covariance Matrix Estimator and a Direct Test for Heteroscedasticity, Econometrica 48, 817-838.

Williamson, O.E. (1964): The Economics of Discretionary Behavior: Managerial Objectives in a Theory of the Firm, New Jersey: Prentice Hall.

Zingales, L. (1998): Corporate Governance, in The New Palgrave Dictionary of Economics and Law, London: Macmillan. 


\section{Endnotes}

${ }^{1}$ See e.g. Porter (1992), Jensen (1993), Blair (1995), Monks and Minow (1995), Berglöf (1997), Keasey et al. (1997), Mayer (1996, 1998), Hopt et al. (1998), Rajan and Zingales (1998), Zingales (1998), OECD (1999) for a broad discussion.

${ }^{2}$ See Jensen and Ruback (1983) for a survey and discussion.

${ }^{3}$ See, more recently, e.g. Porter (1992), Jensen (1993), Roe (1994a,b), Bhide (1993, 1994), Pound (1995), Monks and Minow (1995), Schnitzer (1997). As Bhide (1994, p. 129, p. 131) argues, "Unwittingly, the system [of U.S. securities regulations and disclosure rules] nurtures market liquidity at the expense of good governance. ... U.S. rules that protect investors don't just sustain market liquidity, they also drive a wedge between shareholders and managers. Instead of yielding long-term shareholders who concentrate their holdings in a few companies, where they provide informed oversight and counsel, the laws promote diffused, arm's length stockholding."

${ }^{4}$ See e.g. Shleifer and Vishny (1986) as well as Shleifer and Vishny (1997) for a survey of the field.

${ }^{5}$ See for a survey of European systems of corporate governance e.g. Baums (1996), Mayer (1998), and Hopt et al. (1998).

${ }^{6}$ Bayer and Mannesmann may serve as examples.

${ }^{7}$ In December 1998, 323 domestic corporations with an aggregate market capitalization of 1,822,103 million DM were quoted and officially traded on the Frankfurt stock exchange. At the same time, 2,399 domestic corporations (3,829,375 million DM) were listed on the London stock exchange and 2,722 (17,373,835 million DM) on the New York stock exchange. (Source: Deutsche Börse, Factbook, Frankfurt, http://www.exchange.de). See Boehmer (1999) for a thorough analysis of ownership structures and location of control rights in 430 stock corporations officially traded on the Frankfurt stock exchange in 1996. According to this study, banks, industrial firms, holdings, and insurance companies controlled as large blockholders almost $80 \%$ of the median firm's voting rights, or roughly $50 \%$ of the overall market value of firms officially listed.

${ }^{8}$ See e.g. the criticism levelled by Perlitz and Seeger (1994, 1995) or Audretsch and Elston (1997). The implementation of the so-called Neuer Markt (new market) on which shares in innovative young firms are traded can be seen as a step in the direction of a more market-based system of corporate finance.

${ }^{9}$ See e.g. Baumol (1959), Marris (1964), Williamson (1964), Jensen and Meckling (1976), Fama (1980), Demsetz (1983), Fama and Jensen (1983), Demsetz and Lehn (1985), Jensen (1986, 1988). See Short (1994), Shleifer and Vishny (1997), Zingales (1998) for further discussion.

${ }^{10}$ In Germany, the case of Metallgesellschaft may serve as an example of supervisory board failure. The Deutsche Bank, being represented on the supervisory board as a major debtholder, was regarded responsible for the disaster and scolded in the business press for insufficient and bad monitoring. See Frankel and Palmer (1996) for further discussion.

${ }^{11}$ What insufficient control over a firm's assets means, is nicely depicted by the General Motors example cited in Roe (1994a, XII). In 1990, two 'large' (relative to all other shareholders) 
institutional investors, being dissatisfied with the company's bad performance, wanted to negotiate the implementation of a new CEO with GM's leaders. The management could calmly decline the request - each 'large' shareholder only accounted for less than one per cent of the voting capital. In 1992 GM's top management had to take action after all. As losses piled up to over $\$ 6$ billlion, CEO Robert Stempel was eventually fired.

${ }^{12}$ Having large investors may entail costs of "straightforward expropriation of other investors, managers, and employees; inefficient expropriation through pursuit of personal (non-profit maximizing) objectives; and finally the incentive effects of expropriation on the other stakeholders"(Shleifer and Vishny, 1997, pp. 755).

${ }^{13}$ This U-formed relationship also turned up for the US firms in the sample. Coefficients were insignificantly negative for firms from the UK, France and Canada.

${ }^{14}$ See the discussion in Short (1994, p. 216).

${ }^{15}$ As disclosure of smaller blockholdings was not mandatory during the observation period, the calculated Herfindahl index can only be an approximation to the true degree of ownership concentration. For corporations with missing information on this "dispersed" portion of shareholdings two alternative Herfindahl indices were constructed. One measure treats the "dispersed" portion as one block. Using the means in Table 1 for corporations with only one large shareholder as an example, the Herfindahl index is $(89.07)^{2}+(10.93)^{2}=8,053$. The other measure assumes that the dispersed portion is equally distributed among an unknown number of shareholders, each holding at most $1 \%$ block of stocks, which yields a Herfindahl index of $(89.07)^{2}+10 \times(1.00)^{2}+(0.93)^{2}=7,944$.

${ }^{16}$ The results are available from the authors on request.

${ }^{17}$ The Herfindahl-Index in its standard definition is restricted to take on values between 0 and 10,000. The logit transformation $\log [\mathrm{H} /(10,000-\mathrm{H})]$ yields an "unbounded" variable. In the case of Mannesmann, for which ownership of voting shares is reported to be "100\% dispersed", $\mathrm{H}$ was set at 1 in the transformation. For firms with only one owner holding $100 \%$ of voting stock, $\mathrm{H}$ was set at 9,999. In alternative regression runs we used the bounded Herfindahl-Index as well as the share of the largest shareholder plus its squared value as in Gedajlovic and Shapiro (1998). Further, we replaced ROA by ROE. We also tested more parsimonious specifications, leaving out (some of) the variables implied by industrial organization theory. As the estimates with respect to governance indicators do not differ significantly, we do not report the results from these alternative specifications here. They are available from the authors on request.

${ }^{18}$ See e.g. Hsiao (1986) or Baltagi (1995) for a comprehensive discussion of panel data models and appropriate estimation techniques.

${ }^{19}$ See, however, the interesting theoretical approaches by Burkhart, Gromb, and Panunzi (1997), Bolton and von Thadden (1998) as well as Pagano and Röell (1998).

${ }^{20}$ We tested alternative exclusions of variables, since picking a specific variable is - admittedly arbitrary. The results, however, do not change significantly with respect to the governance indicators if any other variable is excluded.

${ }^{21}$ See the argument advanced above in connection with quoted firms.

${ }^{22}$ See the discussion in Hall and Weiss (1967) and Brealy and Myers (1984, pp. 362). 
${ }^{23}$ See for discussion e.g. Scherer and Ross (1990) or Martin (1993).

${ }^{24}$ The procedure uses Within-OLS to obtain consistent first-step estimates. From the first-step residuals the serial correlation coefficient is estimated. The regression is then transformed to eliminate serial correlation and is re-estimated by GLS, applying White's (1980) procedure to obtain heteroskedaticity-robust standard errors.

${ }^{25}$ As our specification tests show that the firm- and time-specific effects are fixed rather than random, we cannot consider the location-of-control-rights-groups directly in the panel regression by including dummy variables. The problem is that such indicator variables would vary across firms but not in time. Only for the firms included in CHANGE there would be time series variation. Time-invariable variables cannot be estimated in a fixed effects model because they are perfectly correlated with the fixed (i.e., time-constant) individual effects. See Baltagi (1995, p. 11).

${ }^{26}$ See Audretsch and Weigand (1999). 